\title{
DYNAMIC VISCOSITY AS A FUNCTION OF SHEAR RATE: THE COMPARISON OF ESTABLISHED RHEOLOGICAL MODELS WITH THE NEWLY DERIVED RHEOLOGICAL MODEL FOR THE ESTIMATION OF ZERO- AND INFINITE-SHEAR RATE VISCOSITY OF VEGETABLE OILS
}

\author{
SUNNY GOH ENG GIAP ${ }^{1^{*}} \&$ AZIRA AMRAN ${ }^{2}$
}

\begin{abstract}
Viscosity is one of the most important physical parameters that need proper measurement in terms of its accuracy, and to be fitted by rheological model to enable interpolation for unknown viscosity. It would be an advantage if the model estimation could be extended for viscosity extrapolation with reliability. Some models are concerned with the accuracy of predicting viscosity within the experimental range value, while others able to predict viscosity at extreme conditions, for instance, viscosity at infinite- and zero-shear rate conditions. Cross and Carreau are able to model viscosity at extreme conditions, but its estimation value at very low shear rate region could not be justified if the experimental data does not signify the presence of Newtonian behaviour. In this study, coconut, corn, canola, and soy oils were investigated with a viscometer at different shear rates, $3.9-131.6 \mathrm{~s}^{-1}$, and were sheared at specific temperatures, 50 and $90^{\circ} \mathrm{C}$. The experimental data were curve-fitted with wellknown rheological models, and then, a new rheological model was proposed as an alternative equation for viscosity estimation at low shear rate region. Infinite-shear rate viscosity from the new model is consistent with the estimation from well-known models. In addition, results showed that vegetable oil has the characteristic of a pseudoplastic, and the experimental data were well fitted by the new proposed model $\left(\mathrm{R}^{2}>0.96\right)$.
\end{abstract}

Keywords: Viscosity; shear rate; rheology; vegetable oil; Newtonian

Abstrak. Kelikatan merupakan salah satu daripada parameter fizikal penting yang memerlukan pengukuran dengan kejituan, dan supaya ia dapat diwakili dengan persamaan reologi untuk membolehkan interpolasi nilai kelikatan yang tidak diketahui. Persamaan akan mempunyai kelebihan tambahan jika anggaran persamaan mampu memberi anggaran jitu penentuluaran. Sesetengah persamaan adalah mementingkan kejituan ramalan kelikatan dalam julat nilai eksperimen, sementara yang lain pula boleh membuat jangkaan kelikatan pada keadaan lampau, contohnya, kelikatan pada keadaan infiniti- and sifar-keterikan. Persamaan Cross and Carreau mampu untuk memberi nilai kelikatan pada keadaan lampau, tetapi anggaran keterikan awalan tidak boleh ditentusahkan jika data eksperimen tidak menunjukkan kewujudan sifat Newtonian. Dalam kajian ini, minyak tumbuhan kelapa, jagung, canola, dan soya dikaji dengan menggunakan viskometer pada keterikan yang berlainan, $3.9-131.6 \mathrm{~s}^{-1}$, dan keterikan adalah dilakukan pada suhu, 50 dan $90^{\circ} \mathrm{C}$. Data eksperimen dipadankan dengan persamaan-persamaan reologi yang terkenal, dan kemudiannya, satu persamaan reologi baru diperkenalkan sebagai persamaan altenatif kepada pengiraan kelikatan pada kawasan keterikan rendah. Infiniti-keterikan kelikatan daripada persamaan baru adalah setara dengan nilai-nilai daripada persamaan-

$\overline{1 \& 2}$ Department of Engineering Science, Faculty of Science and Technology, Universiti Malaysia Terengganu, Mengabang Telipot, 21030 Kuala Terengganu, Terengganu, Malaysia

* Corresponding author: sunnyg@umt.edu.my 
persamaan reologi terkenal. Di samping itu, keputusan menunjukkan kelikatan minyak tumbuhan mempunyai ciri pseudoplastic, dan data eksperimen dapat dimodelkan dengan persamaan baru dengan baik $\left(\mathrm{R}^{2}>0.96\right)$.

Kata kunci: Kelikatan; keterikan; reologi; minyak tumbuhan; Newtonian

\subsection{INTRODUCTION}

\subsection{Viscosity as a function of variables}

In fluid, when the increasing shear stress is proportional with increasing shear rate, it is known as Newtonian fluid [1]. The ratio of shear stress and shear rate gives a constant, which is known as viscosity. In a situation where a shear stress is created with a smaller shear rate, the fluid is claimed as having a higher viscosity. For a fluid to behave as Newtonian, any increase in shear stress should be accompanied with a similar portion increase of shear rate which would result in a constant viscosity. This behaviour indicates the independence of fluid viscosity on the shear rate.

However, in reality, fluid does not behave as a Newtonian fluid. In the case of vegetable oil, viscosity is found to reduce as the shear rate increases [2]. This behaviour is better known as pseudoplastic or shear-thinning behaviour. Similar observation is also observed for emulsions, paste, soy protein plastic, etc [3-5]. Viscosity changes could begin with a temporary Newtonian behaviour as the shear rate begins to apply on a stagnant fluid. Viscosity would continue to reduce if the shear rate continues to increase, for which the observed behaviour is known as pseudoplastic. Over an extended range of shear rate increment, viscosity would eventually level off, which again gives a Newtonian region [6].

Apart from shear rate, viscosity could be reduced due to liquid body temperature increased. Temperature dependence of viscosity is observed for paint, waxy oils, fatty acid composition, sesame seed oil, etc [7-10]. Moreover, some other variables also have contribution on the changes of viscosity, which include composition, moisture, pressure, oil degradation, etc [11-14]. Since the intention of the current study is to solve viscosity estimation at low shear rate region, discussion in the following section is limited to the shear rate dependence of rheological models.

\subsection{RHEOLOGICAL MODEL AS A FUNCTION OF SHEAR RATE}

Viscosity as a function of shear rate could be modelled by some well-known rheological model. These models are known as power-law, Cross, Carreau, Bingham, HerschelBulkley, Casson, Sisko, etc [15]. The power-law, Cross, Carreau, Herschel-Bulkley models are listed as below in sequence:

$$
\eta=K_{P} \gamma^{n_{P}-1}
$$




$$
\begin{gathered}
\eta=\eta_{\infty, \gamma}+\frac{\eta_{o, \gamma}-\eta_{\infty, \gamma}}{1+\left(\alpha_{c} \gamma\right)^{m}} \\
\eta=\eta_{\infty, \gamma}+\frac{\eta_{o, \gamma}-\eta_{\infty, \gamma}}{\left[1+\left(\lambda_{c} \gamma\right)^{2}\right]^{N}} \\
\eta=K_{H} \gamma^{n_{H}-1}+\eta_{\infty, \gamma}
\end{gathered}
$$

where: $K_{P}$ and $K_{H}$ are consistency index $\left(\mathrm{Pa} . \mathrm{s}^{\mathrm{n}}\right) ; n_{P}$ and $n_{H}$ are flow behaviour index (dimensionless); $\eta$ is dynamic viscosity (Pa.s); $\eta_{\infty, \gamma}$ is viscosity at infinite-shear rate (Pa.s); $\eta_{o, \gamma}$ is viscosity at zero-shear rate $(\mathrm{Pa} . \mathrm{s}) ; \gamma$ is shear rate $\left(\mathrm{s}^{-1}\right) ; m$ and $N$ are constant (dimensionless); and $\lambda_{c}$ and $\alpha_{c}$ are characteristic relaxation time (s).

\subsection{DERIVATION OF A NEW RHEOLOGICAL MODEL}

For shear-thinning behaviour, viscosity reduces with increasing shear rate, and the viscosity reduces exponentially as the shear rate increased. This relationship could be written as following:

$$
\eta \propto \frac{1}{\gamma^{n}}
$$

Thus,

$$
\eta=\frac{a}{\gamma^{n}}
$$

In order to allow asymptote relocation at viscosity $(\eta)$ - and shear rate $(\gamma)$-axes, constants $b$ and $c$ are introduced into the equation to give:

$$
(\eta-b)=\frac{a}{(\gamma-c)^{n}}
$$

At separate solution to the equation, when $\gamma \rightarrow+\infty$, and then when $\gamma \rightarrow 0$, it gives:

$$
\eta=\frac{\eta_{o, \gamma}-\eta_{\infty, \gamma}}{\left(\frac{\gamma}{-b}+1\right)^{n}}+\eta_{\infty, \gamma}
$$

This equation approximates Cross and Carreau models, but it would generate significant different value of viscosity estimation at low shear rate region. To avoid any estimation of viscosity that behaved alike to Newtonian at a very low shear rate region, the constant $-b$ is assumed as unity in the equation, which gives: 


$$
\eta=\frac{\eta_{o, \gamma}-\eta_{\infty, \gamma}}{(\gamma+1)^{n}}+\eta_{\infty, \gamma}
$$

For shear-thinning fluid,

$$
\eta_{o}>\eta_{\infty}
$$

For Newtonian fluid,

$$
\eta=\eta_{o}
$$

Equation (9) is proposed as a new equation to model viscosity at zero-shear rate $\left(\eta_{o, \gamma}\right)$, the region where viscosity reduces as shear rate increased.

\subsection{OBJECTIVES OF THE STUDY}

In the current work, the objectives of the study are to: (1) evaluate the viscosity of four vegetable oils as a function of shear rate; (2) model experimental data with power-law, Cross, Carreau, Herschel-Bulkley, and the current proposed new rheological model; and (3) compare viscosity value of oils at zero-shear rate between Cross, Carreau, and new proposed model.

\subsection{METHODOLOGY}

Viscosity measurement was carried out on soy, corn, canola, and coconut oils were purchased locally as food grade vegetable oils.

A Brookfield (Viscometer model DV-I+) rotational-type viscometer was used to measure the viscosity of oil samples. Before use, the viscometer (accuracy, $\pm 1 \%$ fullscale range; repeatability, $0.2 \%$ full-scale range) was calibrated with $4.7 \mathrm{cP}$ Brookfield silicone viscosity standard. The viscosity of the oils was measured in triplicate at ten different shear rates. SP-18 spindle was operated at different speeds between 3 and 100 $\mathrm{rpm}$. A temperature controller (temperature accuracy of $\pm 1 \%$ ) was used to increase the temperature of the oil samples from 50 up to $90{ }^{\circ} \mathrm{C}$. For each temperature, the oil samples were left for 15 minutes until steady-state heat transfer was achieved.

In the viscometer, it allowed presetting of the operational rotational speed in revolution per minute. A built-in sensor in the viscometer box was able to measure the amount of torque value require to maintain spindle rotation at a preset speed. The viscosity value was calculated base on the ratio of shear stress $(\tau)$ and shear rate $(\gamma)$, which are respectively as follows [16]:

$$
\begin{gathered}
\tau=\frac{M}{2 \pi R_{b}^{2} h} \\
\gamma=1.318 \times N
\end{gathered}
$$


where: $M$ is torque (N.m); $R_{b}$ is radius of the spindle $(\mathrm{m}) ; h$ is height of the spindle (m); and $N$ is rotational frequency of spindle (rpm).

Mathematica was used to conduct regression by fitting the experimental data to Carreau, Cross, power-law, Herschel-Bulkley, and the newly proposed model. The regression was carried out at 50 and $90^{\circ} \mathrm{C}$.

\subsection{RESULTS AND DISCUSSION}

\subsection{Shear rate dependence of vegetable oil viscosity}

At constant temperature, viscosity of vegetable oils was found to decrease as shear rate increases. This shear-thinning behaviour of viscosity was not found to have any evident of significant time dependence effect. The reduction of viscosity was more rapid at the low shear rate region between 3.9 and $20 s^{-1}$. As the shear rate continues to increase, the viscosity of oils approximate a levelling off region, which is better known as Newtonian region. This offset was more apparent as the shear rate continues to increase greater than $80 s^{-1}$. The influence of shear rate on viscosity became less apparent as the temperature increases (Figures 1 and 2).

In order to determine the stability of viscosity with respect to the influence of shear rate, the difference of viscosity between 3 and $60 \mathrm{rpm}$ was calculated. Results showed the following sequence: $\left(\eta_{3-60 r p m}\right)_{\text {Canola }}<\left(\eta_{3-60 r p m}\right)_{\text {Corn }}<\left(\eta_{3-60 r p m}\right)_{\text {Coconut }}<$ $\left(\eta_{3-60 r p m}\right)_{\text {Soy }}$, at $50{ }^{\circ} \mathrm{C}$, whereas at $90^{\circ} \mathrm{C},\left(\eta_{3-60 r p m}\right)_{\text {Coconut }}<\left(\eta_{3-60 r p m}\right)_{\text {Canola }}<$ $\left(\eta_{3-60 r p m}\right)_{\text {Corn }}<\left(\eta_{3-60 r p m}\right)_{\text {Soy }}$. This means that canola and coconut are the most Newtonian oil by having the least changes of viscosity with shear rate at 50 and $90^{\circ} \mathrm{C}$, respectively, and soy oil is the most non-Newtonian at both temperatures. In a relative

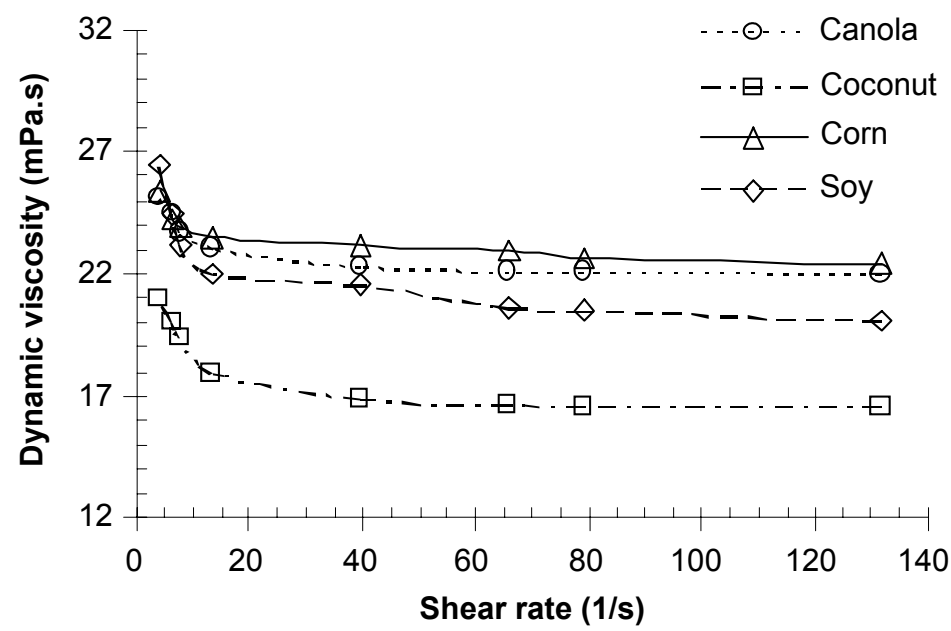

Figure 1 Viscosity as a function of shear rate at 50 degree Celsius for canola, corn, coconut, and soy oils 


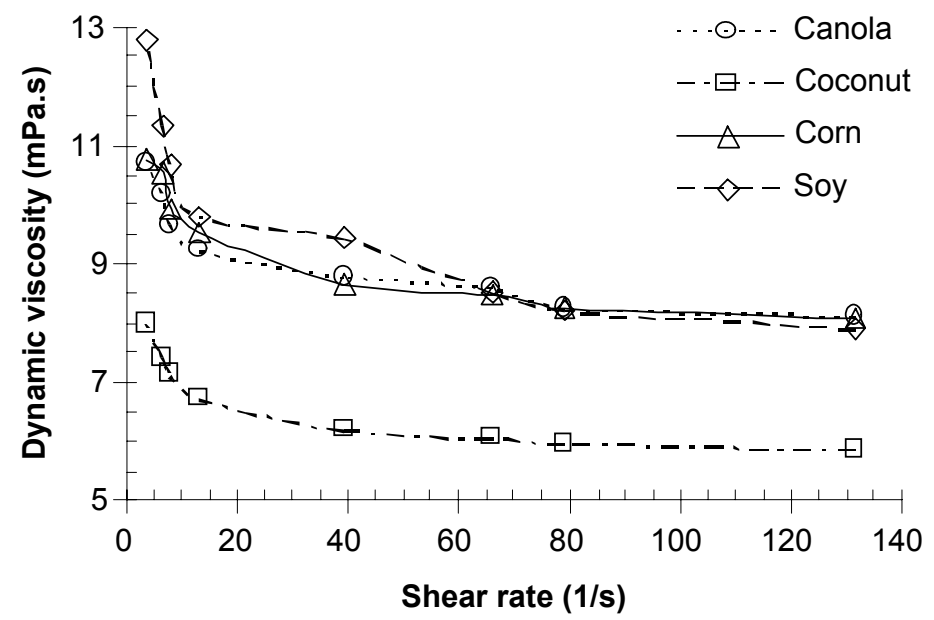

Figure 2 Viscosity as a function of shear rate at 90 degree Celsius for canola, corn, coconut, and soy oils

comparison, among the four vegetable oils, corn and soy are the most viscous oil respectively at 50 and $90^{\circ} \mathrm{C}$, while coconut is the least viscous oil.

\subsection{SHEAR RATE DEPENDENCE OF RHEOLOGICAL MODELS CONSTANTS}

Of all the four well-known models, only Cross and Carreau models are able to give estimated viscosity value at zero-shear rate. The other two equations, power-law and Herschel-Bulkley were discussed with the purpose to provide a complete perspective of relative comparison between each model.

In practical application, $K_{P}$ and $K_{H}$ should indicate viscous level of viscosity. Result in Table 1 shows that the constant $K_{H}$ from Herschel-Bulkley had failed to give reliable indication due to the presence of negative value. As for $K_{P}$ from power-law, it has limited reliability, since the constant value at $50^{\circ} \mathrm{C}$, which was found in the following sequence: $\left(K_{P}\right)_{\text {Soy }}>\left(K_{P}\right)_{\text {Canola }}>\left(K_{P}\right)_{\text {Corn }}>\left(K_{P}\right)_{\text {Coconut }}$, are not the same as those results from graphical observation, which indicates corn as the most viscous oil, before canola, soy, and coconut. Also, a similar problem goes to viscosity at $90{ }^{\circ} \mathrm{C}$.

Flow behaviour index from power-law $\left(n_{P}\right)$ and Herschel-Bulkley $\left(n_{H}\right)$ should carry the indication of Newtonian level. However, at $50{ }^{\circ} \mathrm{C}, n_{P}$ is in the following sequence: $\left(n_{P}\right)_{\text {Corn }}>\left(n_{P}\right)_{\text {Canola }}>\left(n_{P}\right)_{\text {Coconut }}>\left(n_{P}\right)_{\text {Soy }}$ that is not the same as that $\eta_{3-60 r p m}$ sequence in the previous section. Moreover, an indiscriminate value of $n_{H}$ from Herschel-Bulkley has rendered its usefulness in relative comparison between oils. A similar problem is observed as for the constants of $m, N$, and $n_{G}$ (Table 2) from respective Cross, Carreau, and proposed model.

Other than the interpolations of oil properties, Cross, Carreau, Herschel-Bulkley, and proposed model could be used to extrapolate viscosity at extreme conditions, 
Table 1 Estimated value of power-law, Cross, Carreau, and Herschel-Bulkley constants at selected temperatures of 50 and $90{ }^{\circ} \mathrm{C}$

\begin{tabular}{|c|c|c|c|c|c|c|}
\hline Model & $\mathbf{T}\left({ }^{\circ} \mathbf{C}\right)$ & Parameter & Canola & Coconut & Corn & Soy \\
\hline \multirow[t]{6}{*}{ Power-law } & \multirow[t]{3}{*}{50} & $K_{P}$ & $2.59 \mathrm{E}-02$ & $2.25 \mathrm{E}-02$ & $2.59 \mathrm{E}-02$ & $2.78 \mathrm{E}-02$ \\
\hline & & $n_{P}$ & $9.63 \mathrm{E}-01$ & $9.30 \mathrm{E}-01$ & $9.69 \mathrm{E}-01$ & $9.29 \mathrm{E}-01$ \\
\hline & & $\mathrm{R}^{2}$ & 0.92 & 0.92 & 0.89 & 0.89 \\
\hline & \multirow[t]{3}{*}{90} & $K_{P}$ & $1.16 \mathrm{E}-02$ & $8.74 \mathrm{E}-03$ & $1.21 \mathrm{E}-02$ & $1.45 \mathrm{E}-02$ \\
\hline & & $n_{P}$ & $9.24 \mathrm{E}-01$ & $9.11 \mathrm{E}-01$ & $9.14 \mathrm{E}-01$ & $8.72 \mathrm{E}-01$ \\
\hline & & $\mathrm{R}^{2}$ & 0.95 & 0.96 & 0.98 & 0.94 \\
\hline \multirow[t]{8}{*}{ Herschel-Bulkley } & \multirow[t]{4}{*}{50} & $K_{H}$ & $-3.82 \mathrm{E}+02$ & $2.32 \mathrm{E}-02$ & $-3.76 \mathrm{E}+02$ & $1.76 \mathrm{E}-02$ \\
\hline & & $n_{H}$ & $1.00 \mathrm{E}+00$ & $9.34 \mathrm{E}-01$ & $1.00 \mathrm{E}+00$ & $2.14 \mathrm{E}-01$ \\
\hline & & $\eta_{\infty, \gamma}$ & $3.82 \mathrm{E}+02$ & $-7.59 \mathrm{E}-04$ & $3.76 \mathrm{E}+02$ & $2.00 \mathrm{E}-02$ \\
\hline & & $\mathrm{R}^{2}$ & 0.92 & 0.92 & 0.89 & 0.97 \\
\hline & \multirow[t]{4}{*}{90} & $K_{H}$ & $-3.73 \mathrm{E}+02$ & $-3.72 \mathrm{E}+02$ & $-3.70 \mathrm{E}+02$ & 8.82E-02 \\
\hline & & $n_{H}$ & $1.00 \mathrm{E}+00$ & $1.00 \mathrm{E}+00$ & $1.00 \mathrm{E}+00$ & $9.85 \mathrm{E}-01$ \\
\hline & & $\eta_{\infty, \gamma}$ & $3.73 \mathrm{E}+02$ & $3.72 \mathrm{E}+02$ & $3.70 \mathrm{E}+02$ & $-7.44 \mathrm{E}-02$ \\
\hline & & $\mathrm{R}^{2 \prime}$ & 0.94 & 0.94 & 0.97 & 0.93 \\
\hline \multirow[t]{10}{*}{ Cross } & \multirow[t]{5}{*}{50} & $\eta_{\infty, \gamma}$ & $2.20 \mathrm{E}-02$ & $1.66 \mathrm{E}-02$ & $2.25 \mathrm{E}-02$ & $2.02 \mathrm{E}-02$ \\
\hline & & $\eta_{o, \gamma}$ & $2.69 \mathrm{E}-02$ & $2.16 \mathrm{E}-02$ & $1.25 \mathrm{E}+01$ & $2.24 \mathrm{E}+01$ \\
\hline & & $\alpha_{c}$ & $1.74 \mathrm{E}-01$ & $1.15 \mathrm{E}-01$ & $5.05 \mathrm{E}+03$ & $2.09 \mathrm{E}+03$ \\
\hline & & $m$ & $1.42 \mathrm{E}+00$ & $2.30 \mathrm{E}+00$ & $8.47 \mathrm{E}-01$ & $9.07 \mathrm{E}-01$ \\
\hline & & $\mathrm{R}^{2}$ & 0.99 & 1.00 & 0.97 & 0.98 \\
\hline & \multirow[t]{5}{*}{90} & $\eta_{\infty, \gamma}$ & $7.75 \mathrm{E}-03$ & $5.67 \mathrm{E}-03$ & $9.28 \mathrm{E}-03$ & $7.50 \mathrm{E}-03$ \\
\hline & & $\eta_{o, \gamma}$ & $1.51 \mathrm{E}-01$ & $1.69 \mathrm{E}-02$ & $3.59 \mathrm{E}+00$ & $6.92 \mathrm{E}-01$ \\
\hline & & $\alpha_{c}$ & $3.43 \mathrm{E}+02$ & $1.53 \mathrm{E}+00$ & $-1.48 \mathrm{E}+00$ & $9.39 \mathrm{E}+02$ \\
\hline & & $m$ & $5.34 \mathrm{E}-01$ & $7.50 \mathrm{E}-01$ & $3.84 \mathrm{E}+00$ & $5.95 \mathrm{E}-01$ \\
\hline & & $\mathrm{R}^{2}$ & 0.98 & 1.00 & & 0.97 \\
\hline \multirow[t]{10}{*}{ Carreau } & \multirow[t]{5}{*}{50} & $\eta_{\infty, \gamma}$ & $2.19 \mathrm{E}-02$ & $1.66 \mathrm{E}-02$ & $2.25 \mathrm{E}-02$ & $2.02 \mathrm{E}-02$ \\
\hline & & $\eta_{o, \gamma}$ & $2.62 \mathrm{E}-02$ & $2.18 \mathrm{E}-02$ & $5.42 \mathrm{E}-01$ & $7.84 \mathrm{E}-01$ \\
\hline & & $\lambda_{c}$ & $2.12 \mathrm{E}-01$ & $1.06 \mathrm{E}-01$ & $1.19 \mathrm{E}+02$ & $5.05 \mathrm{E}+01$ \\
\hline & & $N$ & $5.89 \mathrm{E}-01$ & $1.20 \mathrm{E}+00$ & $4.23 \mathrm{E}-01$ & $4.53 \mathrm{E}-01$ \\
\hline & & $\mathrm{R}^{2}$ & 0.99 & 1.00 & 0.97 & 0.98 \\
\hline & \multirow[t]{5}{*}{90} & $\eta_{\infty, \gamma}$ & 7.73E-03 & $5.57 \mathrm{E}-03$ & $6.31 \mathrm{E}-03$ & $7.48 \mathrm{E}-03$ \\
\hline & & $\eta_{o, \gamma}$ & $4.27 \mathrm{E}-02$ & $2.46 \mathrm{E}-02$ & $1.35 \mathrm{E}-02$ & $1.13 \mathrm{E}-01$ \\
\hline & & $\lambda$ & $2.83 \mathrm{E}+01$ & $-7.82 \mathrm{E}+00$ & $1.31 \mathrm{E}+00$ & $4.31 \mathrm{E}+01$ \\
\hline & & $N$ & $2.61 \mathrm{E}-01$ & $3.01 \mathrm{E}-01$ & $1.38 \mathrm{E}-01$ & $2.94 \mathrm{E}-01$ \\
\hline & & $\mathrm{R}^{2}$ & 0.98 & 1.00 & 0.99 & 0.97 \\
\hline
\end{tabular}

such as those infinite- and zero-shear rate viscosity. The viscosity of infinite-shear rate from Carreau, at $50^{\circ} \mathrm{C}$, is in the following sequence: $\left(\eta_{\infty, \gamma}\right)_{\text {Corn }}>\left(\eta_{\infty, \gamma}\right)_{\text {Canola }}>\left(\eta_{\infty, \gamma}\right)_{\text {Soy }}$ $>\left(\eta_{\infty, \gamma}\right)_{\text {Coconut }}$, and at $90{ }^{\circ} \mathrm{C}:\left(\eta_{\infty, \gamma}\right)_{\text {Canola }}>\left(\eta_{\infty, \gamma}\right)_{\text {Soy }}>\left(\eta_{\infty, \gamma}\right)_{\text {Corn }}>\left(\eta_{\infty, \gamma}\right)_{\text {Coconut }}$. This sequence for both temperatures has a similar trend of that infinite-shear rate viscosity estimated by proposed model. By calculating the difference in infinite-shear rate viscosity of proposed model with those of Cross and Carreau, it gives $0.038-7.26 \%$ of proposed 
Table 2 Estimated value of proposed model constants at selected temperatures of 50 and $90{ }^{\circ} \mathrm{C}$

\begin{tabular}{lllllll}
\hline Model & $\mathbf{T}\left({ }^{\circ} \mathbf{C}\right)$ & Parameter & Canola & Coconut & Corn & Soy \\
\hline Proposed model & 50 & $\eta_{\infty, \gamma}$ & $2.17 \mathrm{E}-02$ & $1.60 \mathrm{E}-02$ & $2.26 \mathrm{E}-02$ & $2.03 \mathrm{E}-02$ \\
& & $\eta_{o, \gamma}$ & $3.36 \mathrm{E}-02$ & $3.34 \mathrm{E}-02$ & $3.68 \mathrm{E}-02$ & $5.58 \mathrm{E}-02$ \\
& $n$ & $7.89 \mathrm{E}-01$ & $7.77 \mathrm{E}-01$ & $1.03 \mathrm{E}+00$ & $1.10 \mathrm{E}+00$ \\
& \multirow{2}{*}{90} & $\mathrm{R}^{2}$ & 0.99 & 0.99 & 0.97 & 0.98 \\
& $\eta_{\infty, \gamma}$ & $7.89 \mathrm{E}-03$ & $5.67 \mathrm{E}-03$ & $6.81 \mathrm{E}-03$ & $7.71 \mathrm{E}-03$ \\
& $\eta_{o, \gamma}$ & $1.58 \mathrm{E}-02$ & $1.32 \mathrm{E}-02$ & $1.39 \mathrm{E}-02$ & $2.33 \mathrm{E}-02$ \\
& $n$ & $6.47 \mathrm{E}-01$ & $7.36 \mathrm{E}-01$ & $3.56 \mathrm{E}-01$ & $7.23 \mathrm{E}-01$ \\
& $\mathrm{R}^{2}$ & 0.98 & 1.00 & 0.99 & 0.97
\end{tabular}

model for 15 out of 16 data, except one value at $36.3 \%$. Although this could not prove the validity of $\eta_{\infty, \gamma}$ value, at least, it shows the consistency of proposed model to those well-known models.

\subsection{ZERO-SHEAR RATE VISCOSITY FROM CROSS, CARREAU, AND PROPOSED MODEL}

The extrapolation of viscosity value other than those experimental data to estimate zero-shear rate viscosity is shown in Figure 3. An oil in a stagnant condition is about to flow when an initial amount of shear stress is applied to it. The nature of oil to resist the shear stress at this initial stage is known as zero-shear rate viscosity. Due to its existence at a very low shear rate or approximately zero shear rate, practical measurement by

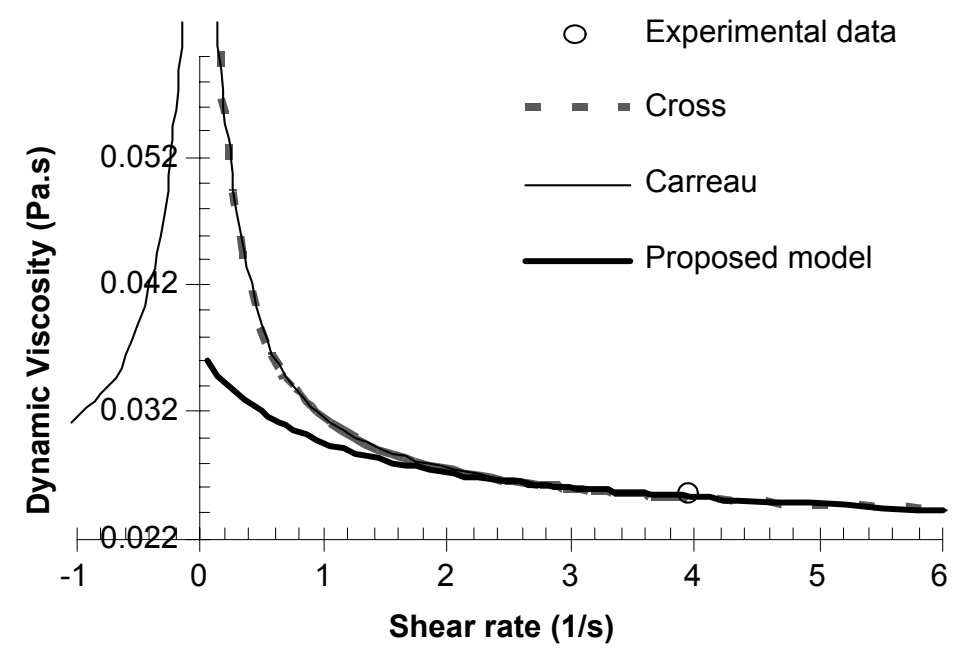

Figure 3 Viscosity as a function of shear rate at 50 degree Celsius for corn oil modelled by Cross, Carreau, and proposed model. The $\eta_{o, \gamma}$ prediction from Cross and Carreau is 33770 and $1372 \%$ greater than that of estimate from proposed model 
viscometer that only allowed a discrete preset value of rotational speed at a time, which make this measurement almost impossible. Thus, the best approach is to estimate this value with an equation.

Cross and Carreau models are capable of estimating zero-shear rate viscosity. Since the graphs in Figures 1 and 2 show that viscosity as a function shear rate are unable to signify the presence Newtonian behaviour at its very low shear rate region, there could be non-existence of Newtonian region for vegetable oils (Figure 4). As such, an alternative model is proposed to contribute as another possible estimation for the current uncertainty. Figure 3 shows that the estimated value from the proposed model is lower than those of Carreau and Cross models. The percentage of zero-shear rate viscosity of Cross and Carreau is ranged from as low as 3.2 to as far as greater than 100 $\%$ of the proposed model. Hence, a further study on vegetable oil viscosity at very low shear rate region should be carried to further justify the reliable of which model fits the best on the experimental data observation.

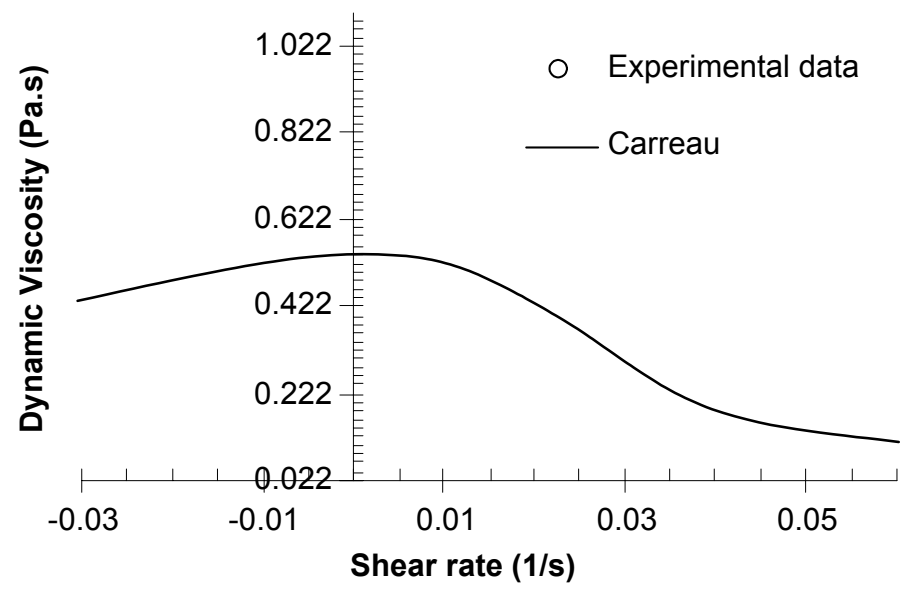

Figure 4 Viscosity as a function of shear rate at 50 degree Celsius for corn oil modelled by Carreau at enlarge scale from Figure 3

\subsection{CONCLUSIONS}

Viscosity was found to decrease as the shear rate increases, and its influence could be reduced from the increase of temperature, which suggests that the vegetable oils are approaching Newtonian behaviour as temperature increases. Cross and Carreau models are able to extrapolate the value of zero-shear rate viscosity, however, this estimated value comes with the presence of Newtonian region, which has raised the question about the reliability of estimation. In response to this uncertainty and also the nonexistence of Newtonian at the very low shear rate region of tested vegetable oils, a new rheological model is proposed, which gives a far smaller zero-shear rate viscosity. Overall, the proposed model gives a good correlation on experimental data with R- 
squared value ranged $0.97-1.00$ for both temperatures of 50 and $90{ }^{\circ} \mathrm{C}$ on the tested vegetable oils.

\section{ACKNOWLEDGEMENTS}

The authors greatly acknowledge the assistance of science officer, Mr. Mahmood Sulaiman, and the laboratory technicians, Mr. Rozimi, and Mrs. Siti Zalaikhar for their indirect contribution in completing the experimentation.

\section{REFERENCES}

[1] Goh, E. G., W. B. Wan Nik, M. Fadhli Ahmad, and A. Amran. 2009. The Assessment of Rheological Model Reliability in Lubricating Behaviour of Vegetable Oils. National Tribology Conference, 58-65.

[2] Ceriani, R., F. R. Paiva, C. B. Gonçalves, E. A. C. Batista, and A. J. A. Meirelles. 2008. Densities and viscosities of vegetable oils of nutritional value. Journal of Chemical and Engineering Data. 53(8): 18461853.

[3] Maskan, M., and F. Gogus. 2000. Effects of sugar on the rheological properties of sunflower oil-water emulsions. Journal of Food Engineering. 43: 173-177.

[4] Di Renzo, G. C., and G. Colelli. 1997. Flow behaviour of olive paste. Applied Engineering in Agriculture. 13(6): 751-755.

[5] Ralston, B. E., and T. A. Osswald. 2008. Viscosity of soy protein plastics determined by Screw-Driven Capillary Rheometry. J Polym Environ. 16: 169-176.

[6] Rao, M.A. 1999. Rheology of fluid and semisolid foods: Principles and Applications, Aspen Publishers, Inc., Gaithersburg, Marylan. 31-34.

[7] Armelin, E., M. Marti, E. Rude, J. Labanda, J. Llorens, and C. Aleman. 2006. A simple model to describe the thixotropic behavior of paints. Progress in organic coatings. 57: 229-235.

[8] Al-Zahrani, S. M., and T. F. Al-Fariss. 1998. A general model for the viscosity of waxy oils. Chemical Engineering and Processing: Process Intensification. 37(5): 433-437.

[9] Fasina, O. O., H. Hallman, M. Craig-Schmidt, and C. Clements. 2006. Predicting temperature-dependence viscosity of vegetable oils from fatty acid composition. Journal of the American Oil Chemists' Society. 83(10): 899-903

[10] Akinoso, R., and J. C. Igbeka. 2006. Modelling of oil expression from sesame seed. Journal of Food Science and Technology. 43(6): 612-614.

[11] Hae Ryu, C., Y. Chan Bae, S. Hwan Lee, S. Yi, and Y. H. Park. 1998. Rheological properties of hollow sphere loaded polymer melts. Polymer. 39(25): 6293-6299.

[12] Akdogan, H., and T. H. McHugh. 1999. Twin screw extrusion of peach puree: Rheological properties and product characteristics. Journal of Food Processing and Preservation. 23(4): 285-305.

[13] Novak, L. T. 2006. Entity-based eyring - NRTL viscosity model for mixtures containing oils and bitumens. Industrial and Engineering Chemistry Research. 45(21): 7329-7335.

[14] Benedito, J., J. V. García-Pérez, M. Carmen Dobarganes, and A. Mulet. 2007. Rapid evaluation of frying oil degradation using ultrasonic technology. Food Research International. 40(3): 406-414.

[15] Wan Nik, W. B., F. N. Ani, H. H. Masjuki, and S. G. Eng Giap. 2005. Rheology of bio-edible oils according to several rheological models and its potential as hydraulic fluid. Industrial Crops and Products. 22: 249-255.

[16] Brookfield Engineering Laboratories. 2005. More solution to sticky problems: a guide to getting more from your Brookfield viscometer, Brookfield Engineering Laboratories, Inc., Middlebore, USA. 